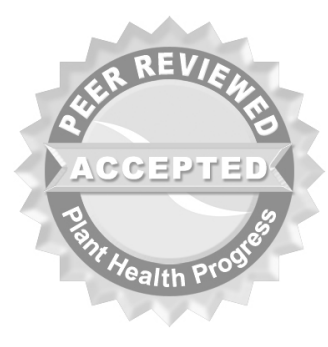

(c) 2005 Her Majesty the Queen in right of Canada, Natural Resources Canada, Canadian Forest Service.

Accepted for publication 15 May 2005. Published 21 J une 2005.

\title{
First Report of Powdery Mildew of Mahonia aquifolium (Pursh.) Nutt. Caused by Erysiphe (Microsphaera) berberidis (DC.) Lév in Canada
}

\author{
Shiguang Zhao and Simon F. Shamoun, Natural Resources \\ Canada, Canadian Forest Service, Pacific Forestry Centre, 506 West \\ Burnside Road, Victoria, BC V8Z 1M5, Canada \\ Corresponding author: Simon F. Shamoun. sshamoun@nrcan.gc.ca \\ Zhao, S., and Simon, F. S. 2005. First report of powdery mildew of Mahonia aquifolium \\ (Pursh.) Nutt. caused by Erysiphe (Microsphaera) berberidis (DC.) Lév in Canada. Online. \\ Plant Health Progress doi: 10.1094/PHP-2005-0621-01-HN.
}

Mahonia aquifolium (Pursh.) Nutt. (syn. Berberis aquifolium Pursh.) (Tall Oregon Grape) is a plant native to British Columbia, Canada, and the coastal Pacific Northwest of the USA. This species is utilized by landscapers as an ornamental for its holly-like leaves, upright growth habit, colorful berries and foliage. In addition, it has been used as a medicinal plant, and as a dye and food source in North America and Europe $(1,2)$. The first discovery of powdery mildew of Mahonia aquifolium in the USA was reported in Washington State in 2003, and the pathogen was identified as Microsphaera berberidis (DC.) Lév (Erysiphe berberidis) (5). In Canada, powdery mildew of Oregon grape was discovered in the early summer of 2004 in Victoria, British Columbia. The diseased leaves were covered on both sides with whitish patches of mycelium and conidia (Fig. 1). The fungal colonies infected leaves and petioles (Fig. 2); as well as sepals, berries (Fig. 3), and young stems. With severe infection, young leaves and stems were greatly damaged, desiccated, and eventually necrotic. Most of the infected leaves turned red in winter. The disease appeared to develop only in the shade, as no visual signs or symptoms were observed in open areas. Conidia of the causal fungus were cylindric (Fig. 4), with rounded ends when fresh (dried spores usually had flat ends), measuring 23-46 × 11-17 $\mu \mathrm{m}$ (average $38 \times 13 \mu \mathrm{m}$ ); the conidiophores (Fig. 5) had straight, cylindric foot- cells of 21-38 $\times 6.5-8 \mu \mathrm{m}$. Conidia were frequently found single or in short chains of 2 to 3. Short germ tubes were produced on the ends of conidia placed on water agar. No teleomorphic form of this fungus was observed. The disease symptoms and fungal morphology described here are similar, if not identical, to powdery mildew of Mahonia aquifolium caused by Microsphaera berberidis in the USA (5). According to Braun et al. (3), this mildew is therefore identified and named as Erysiphe (Microsphaera) berberidis. To our knowledge, this is the first record of powdery mildew caused by E. berberidis on Oregon grape in Canada (4). A voucher specimen was deposited at the Pacific Forestry Center Herbarium (DAVFD No: 28734). 


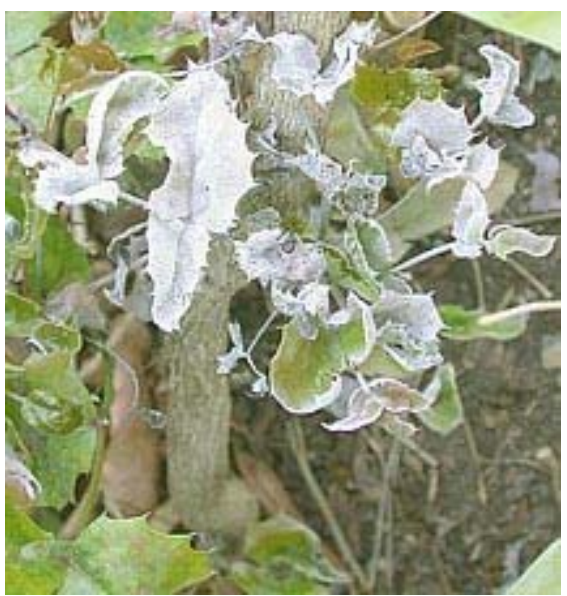

Fig. 1. Powdery mildew infection of Mahonia aquifolium on leaves.

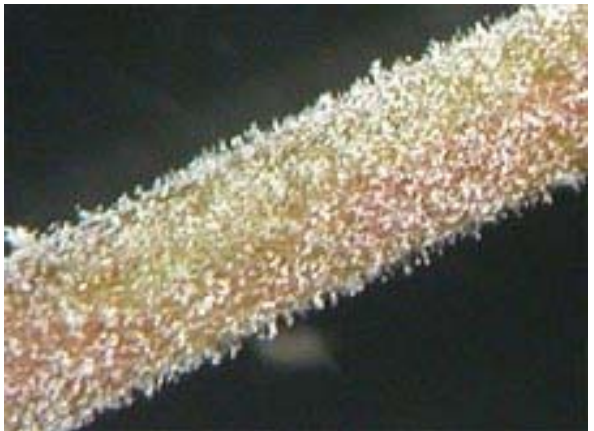

Fig. 2. Powdery mildew infection of Mahonia aquifolium on petiole.

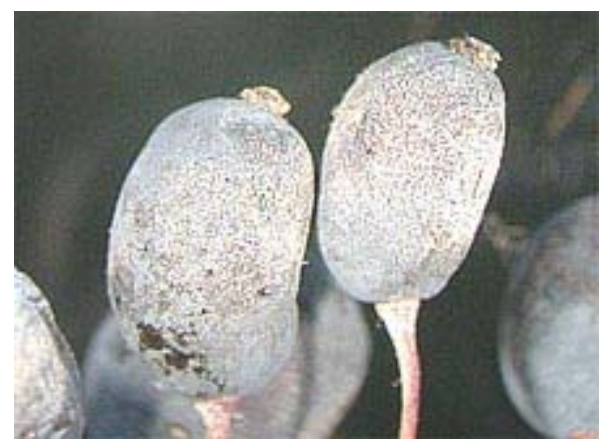

Fig. 3. Powdery mildew infection of Mahonia aquifolium on berries.

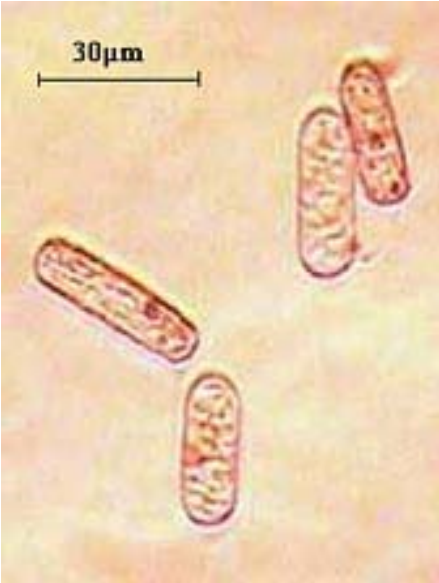

Fig. 4. Conidia of Erysiphe berberidis formed on Mahonia aquifolium.

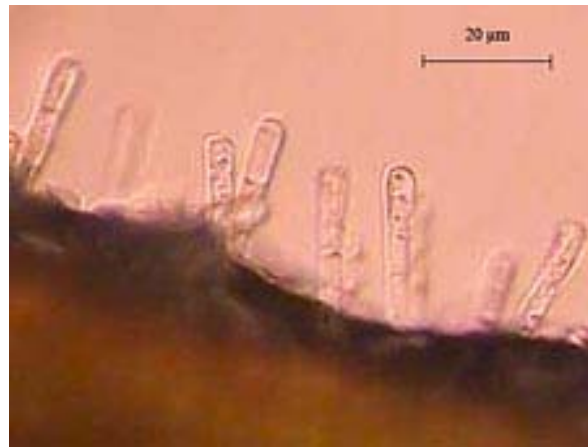

Fig. 5. Conidiophores of Erysiphe berberidis formed on Mahonia aquifolium. 
Literature Cited

1. Abrams, L. 1950. Illustrated Flora of the Pacific States. Vol. 2. Stanford University Press, Stanford, CA.

2. Auge, H., and Brandl, R. 1997. Seedling recruitment in the invasive clonal shrub, Mahonia aquifolium (Pursh) Nutt. Oecologia Berlin 110:205-211.

3. Braun, U., Cook, R. T. A., Inman, A. J., and Shin, H. D. 2002. The taxonomy of the powdery mildew fungi. Pages 13-55 in: The Powdery Mildews: A Comprehensive Treatise. R. R. Bélanger, W. R. Bushnell, A. J . Dik, and T. L. W. Carver, eds. American Phytopathological Society, St Paul, MN.

4. Fernando, A., Ring, F., Lowe, D., and Callan, B. 1999. Index of plant pathogens, plant-associated microorganisms, and forest fungi of British Columbia. Natural Resource Canada, Canada Forest Service, Pacific Forestry Center, Victoria, BC. Information Report BL-X-385.

5. Glawe, D. A. 2003. First report of powdery mildew of Mahonia aquifolium caused by Microsphaera berberidis (Erysiphe berberidis) in North America. Plant Health Progress doi:10.1094/ PHP-2003-0206-01-HN. 